\title{
Postneoadjuvant Therapy Pathologic TNM
} Finding

National Cancer Institute

\section{Source}

National Cancer Institute. Postneoadjuvant Therapy Pathologic TNM Finding. NCI

Thesaurus. Code C133398.

Pathologic TNM staging performed with access to postneoadjuvant therapy information only. 